\title{
How Twitter Works in Public Transportation: A Case Study of Bus Rapid Transit in Jakarta and Semarang
}

\author{
Surya Hidayat Bokings ${ }^{1 *}$, Achmad Nurmandi ${ }^{2}$, and Mohammad Jafar Loilatu ${ }^{3}$ \\ ${ }^{1-3}$ Master of Government Affairs and Administration, Muhammadiyah University of Yogyakarta \\ Daerah Istimewa Yogyakarta 55183, Indonesia \\ Email: ${ }^{1}$ yatbokings@gmail.com, ${ }^{2}$ nurmandiachmad@gmail.com, ${ }^{3}$ jafar.loilatu@gmail.com
}

\begin{abstract}
The research focuses on using social media (Twitter) as a medium for public transportation services (Bus Rapid Transit - BRT) in Semarang and Jakarta. The research uses Nvivo 12 Plus as a tool in qualitative research methods. The results show that the function regarding Twitter accounts of BRT in Semarang and Jakarta has several differences. The difference is based on information integration services, interaction information and transparency, and adaptive and responsive information services. In conclusion, the information integration on Twitter accounts of BRT in Semarang and Jakarta services works well, but a more dominant function is found in BRT in Jakarta. The Twitter account of BRT in Jakarta provides more information on transportation routes, such as the number of routes and fleets. BRT in Jakarta is a responsive account, responding to questions or mentions given by its users. The high level of activity makes the BRT Jakarta account more active. Moreover, the form of information conveyed by the Twitter account of BRT Semarang has its characteristics because it shows more the character of the region (Central Java).
\end{abstract}

Index Terms-Twitter, Public Transportation, Bus Rapid Transit in Semarang, Bus Rapid Transit in Jakarta

\section{INTRODUCTION}

B IG cities like Jakarta, Surabaya, Semarang, and Bandung use public transportation as the main transportation. It is especially in Semarang and Jakarta as provincial capitals in two major provinces, Jakarta and Central Java. Semarang is currently implementing public transportation following the trends of the development of smart cities. Both cities are large cities with a high population density. With a high population density, community mobility is also high. To overcome this mobility, public transportation has to be provided as the main transportation mode replacing private transportation [1]. The number of private

Received: April 19, 2020; received in revised form: June 02, 2020; accepted: June 02, 2020; available online: Sep. 09, 2020. *Corresponding Author transportations in Indonesia is dominated by private vehicles (98.9 million motorcycles, 13.5 million private cars, 6.6 million freight cars, and 2.4 million buses). The number of users in private transportation in Jakarta exceeds the number of public vehicles. According to a Jakarta statistics institution report, the use of private transportation has increased from year to year to a total of 15 million motorcycles, 3.9 million cars, 763 thousand freight vehicles, and 329 thousand buses [2]. However, the number of vehicles in Semarang compared to Jakarta is far less.

As a modern communication tool, social media becomes part of Information Communication and Technology (ICT). Social media is a door for humans to connect with the surrounding environment and convey information such as knowledge, environment, weather conditions, and natural disasters [3]. Social media is a revolution of Web 2.0 technology. It combines more modern and innovative technologies to address the complexity of the city and create sustainable development [4].

Social media offers a more efficient function for promotion and increasing interaction between stakeholders and the community [5]. It can be used as two-way communication and interaction between users, such as stakeholder organizations and service providers [6]. It is also useful for monitoring the city by identifying places or events and transferring information through social media real-time [7]. Moreover, it displays very useful information for the community because there are various data in it. There has been many studies on social media and web 2.0 , especially public services [5]. However, there is still limited research focusing on the delivery of information, especially in public transportation.

Digital transformation brings changes to the old paradigm. It brings people to a new perspective on the interconnected world, so is the smart city perspec- 
Cite this article as: S. H. Bokings, A. Nurmandi, and M. J. Loilatu, "How Twitter Works in Public Transportation: A Case Study of Bus Rapid Transit in Jakarta and Semarang", CommIT (Communication \& Information Technology) Journal 14(2), 53-63, 2020.

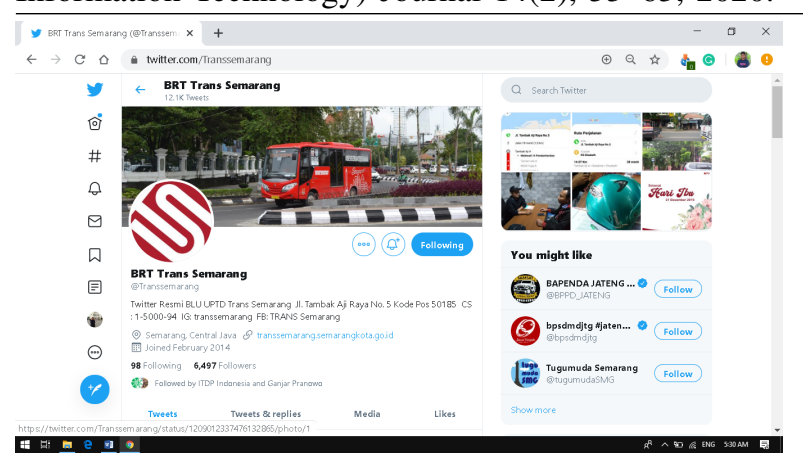

Fig. 1. Twitter account of Bus Rapid Transit in Semarang (Source: @ transsemarang).

tive [8]. Smart transportation is part of the concept of smart cities. Smart cities in several studies are divided into the smart economy, smart environment, smart government, smart people, smart living, and smart mobility [9]. Information in smart cities is usually conveyed through several applications connected with Intelligent Transport Systems (ITS). It has several features and applications for receiving data, translating data, and communicating data to users [10]. It is used to provide good transportation services as a solution for traffic conditions due to traffic jams from private vehicles.

In service quality, the company uses several information platforms to manage its services. Thus, ICT becomes the main element in it. By utilizing ICT, one of the tools to convey information is social media. Social media becomes an information platform in applying the principles of e-governance [11]. Access to information on services by ICT is easy to convey and receive for the community. However, the question is about direct services to the community. Direct services need to pay attention to accessibility based on some of the studies explaining the main points of public facilities and public institutions. Reference [12] simply shows the inclusiveness of open space to community activities, participation, service, respect, and equality. Thus, an inclusive approach is needed to respond to all needs of urban cities [13]. The best approach in inclusive city planning and development is the integration approach that connects all aspects of the city (human, infrastructure, and ICT).

Public transportation is designed to connect passengers with public and sustainable facilities [14]. Management of information provides basic human needs in carrying out activities, integrating information and public transportation, and promoting public transport services, card systems, and Twitter as the main data source in exploring environmental phenomena [15]. The literature on transportation management tends to

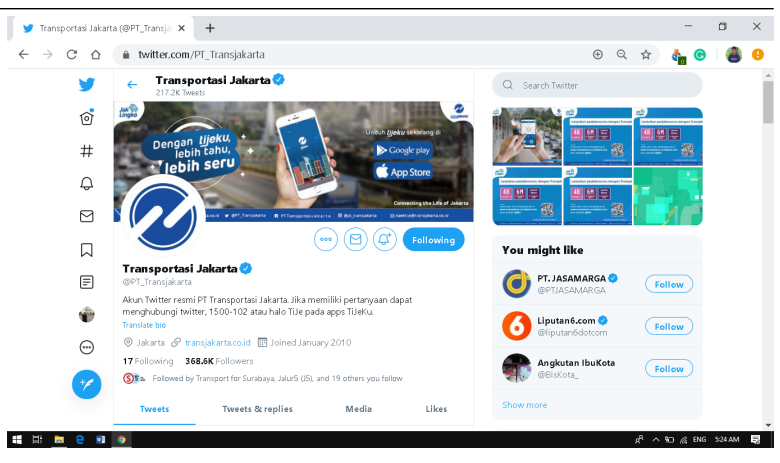

Fig. 2. Twitter account of Bus Rapid Transit in Jakarta (Source: @PT_Transjakarta).

be more on transportation management reliability [16]. Reliability is currently an obstacle for public transportation because it is unable to rely on security. Hence, the things that need to be considered in public transportation are interaction, market, and infrastructure support. The reliability of information can be carried out through a centralized information system. It means that systems are working in mutual support in smart transportation $[16,17]$.

In the research, Twitter is used in public transportation services in the two cities, Semarang and Jakarta. Twitter accounts of @ transsemarang and @PT_Transjakarta provide information about services of Bus Rapid Transit (BRT) in Semarang and Jakarta. These two cities are chosen as research subjects based on population density, traffic congestion, and a high amount of private transportation. So, the research focuses on Twitter as a medium for public transportation services in Semarang and Jakarta. The results are expected to support public transport services using Twitter.

\section{RESEARCH METHOD}

The research applies a qualitative approach. It provides an approach to the subject and explains its function in detail [18]. It aims to answer complex questions about the research subject so that it can be implemented into questions and function in applying research, answering a procedure with the most basic sample, and providing recommendations from the study [19]. The model of data analysis uses Nvivo 12 plus software. Nvivo 12 plus can translate social media data using Ncapture features. The sources of data are the Twitter accounts of BRT in Jakarta and Semarang (see Figs. 1 and 2). The Nvivo 12 Plus analysis uses features of word frequency, group analysis, and text research analysis [20]. The research uses a Qualitative Data Analysis (QDA) model [21]. The analysis model of social media with NVivo 12 Plus is shown in Table I. 
Cite this article as: S. H. Bokings, A. Nurmandi, and M. J. Loilatu, "How Twitter Works in Public Transportation: A Case Study of Bus Rapid Transit in Jakarta and Semarang", CommIT (Communication \& Information Technology) Journal 14(2), 53-63, 2020.

TABLE I

The Analysis of Social Media with NVivo 12 Plus.

\begin{tabular}{|c|c|c|c|c|}
\hline \multicolumn{2}{|c|}{ The level of strategy } & \multirow[t]{2}{*}{ Translated } & \multicolumn{2}{|c|}{ The level of tactics } \\
\hline Level 1 & Level 2 & & Level 4 & Level 5 \\
\hline Objectives & Analytic plan & Translation & Select tools & Constructed tools \\
\hline $\begin{array}{l}\text { @PT_TransJakarta } \\
\text { @ transsemarang }\end{array}$ & Ncapture twitter account & Input data to Nvivo 12 Plus & Word cloud, text search, and visualization & Compare and combination \\
\hline
\end{tabular}

\section{RESUlTS AND DisCUSSION}

The Twitter accounts of BRT in Semarang and Jakarta have their respective characteristics. These characteristics lie in the information model, interaction form, and type of information. They also have quite different characteristics in terms of activity and number of tweets. Twitter account of BRT in Jakarta is more dominant, and the number of tweets is higher. These characteristics can be known based on information such as greetings, how to answer, and forms of interaction. The accounts of BRT in Semarang and Jakarta use several keywords that describe the services provided, such as "rute" (route), "shelter", "halte" (bus stop), "transit", "naik" (ride), "mengalami" (experience). These words also describe the interaction patterns used by the two accounts for BRT users. The following explanation outlines the use of Twitter as a service tool in public transportation.

\section{A. Bus Rapid Transit in Semarang}

The conveyed information characterizes the city as an effort to describe problems such as gaps in using public transportation [22]. The information of BRT in Semarang and Jakarta is delivered through the information platform, as presented earlier. The information platform refers to ICT or a communication tool and uses Twitter as its medium [9]. The communication carried out in the interactive medium is to find out what is needed by the community in transportation services. Table II illustrates the type of information delivered by the Twitter account of BRT in Semarang to its users. The information provided revolves around the service activities carried out by BRT in Semarang. Functionally, this account is active in delivering information about the services performed. Based on the predetermined operational definitions such as integration, a form of information, and service quality, the description in the type of information by BRT in Semarang will cover all three indicators.

Integrated services are services that are connected to certain objects and information. The information conveyed connects services between one point and another. From information conveyed by the Twitter account of BRT in Semarang, several words connect
TABLE II

INFORMATION INTEGRATION OF BUS RAPID TRANSIT IN SEMARANG.

\begin{tabular}{|c|c|c|c|c|}
\hline Word & $\begin{array}{l}\text { Length of } \\
\text { the Word }\end{array}$ & $\begin{array}{r}\text { Count of } \\
\text { Appearance }\end{array}$ & $\%$ & Explanation \\
\hline Koridor & 7 & 1475 & 2.28 & $\begin{array}{l}\text { Information about the } \\
\text { corridor of BRT in } \\
\text { Semarang }\end{array}$ \\
\hline Transit & 7 & 670 & 1.04 & $\begin{array}{l}\text { Information to BRT } \\
\text { users for specific tran- } \\
\text { sit points so they can } \\
\text { board another fleet }\end{array}$ \\
\hline Turun & 5 & 595 & 0.92 & $\begin{array}{l}\text { Information about the } \\
\text { location of the bus } \\
\text { stop in BRT in Se- } \\
\text { marang }\end{array}$ \\
\hline Shelter & 7 & 555 & 0.86 & $\begin{array}{l}\text { Information for BRT } \\
\text { Semarang users } \\
\text { for transitting at } \\
\text { Semarang City Hall }\end{array}$ \\
\hline Arah & 4 & 855 & 1.32 & $\begin{array}{l}\text { Information about the } \\
\text { direction of departing } \\
\text { in BRT in Semarang }\end{array}$ \\
\hline
\end{tabular}

one point to another, such as "koridor" (corridor), "shelter", "turun" (get off), "transit", and "arah" (direction). These five words are service keywords for information integration. Table II explains the words with high numbers. Those are often used by accounts of BRT in Semarang. It is said that communication is built related to integrated services [23]. With social media, information can connect everyone without faceto-face and services between one-stop and another.

Using Nvivo 12 Plus, word frequency analysis shows the comparison of the number of appeared words. The "koridor" is often used with a percentage of $2.28 \%$ (1475 times). The result shows that the information service of BRT in Semarang is related to corridors that are integrated and shelter in each corridor. BRT is a type of mass transportation with a lower passenger volume, but the number of BRT buses is provided in greater numbers. The number of corridors and shelters that are many cause a large distribution of information to minimize service errors and give the need for interaction between two or more people [5].

The words, such as "balaikota" (town hall), "mohon" (please), and "armada" (fleet) represent transparency in@transsemarang (Twitter account of BRT in Semarang) service. These three words are related to services when the users experience problems, so 
Cite this article as: S. H. Bokings, A. Nurmandi, and M. J. Loilatu, "How Twitter Works in Public Transportation: A Case Study of Bus Rapid Transit in Jakarta and Semarang", CommIT (Communication \& Information Technology) Journal 14(2), 53-63, 2020.

TABLE III

INTERACTION INFORMATION AND TRANSPARENCY OF BUS RAPID TRANSIT IN SEMARANG.

\begin{tabular}{|c|c|c|c|c|}
\hline Word & $\begin{array}{l}\text { Length of } \\
\text { the Word }\end{array}$ & $\begin{array}{r}\text { Count of } \\
\text { Appearance }\end{array}$ & $\%$ & Explanation \\
\hline $\begin{array}{l}\text { @ hendrar } \\
\text {-prihadi }\end{array}$ & 15 & 765 & 1.18 & $\begin{array}{l}\text { An account that is an } \\
\text { influencer of BRT in } \\
\text { Semarang }\end{array}$ \\
\hline Balaikota & 9 & 449 & 0.70 & $\begin{array}{l}\text { The location of the } \\
\text { stop and the BRT Se- } \\
\text { marang ride point }\end{array}$ \\
\hline Kami & 4 & 1194 & 1.85 & $\begin{array}{l}\text { The answer to the } \\
\text { users of BRT in Se- } \\
\text { marang about sched- } \\
\text { ule and route informa- } \\
\text { tion. They also apol- } \\
\text { ogize for the users of } \\
\text { BRT in Semarang }\end{array}$ \\
\hline Mohon & 5 & 502 & 0.78 & $\begin{array}{l}\text { Apology of BRT in } \\
\text { Semarang to its users }\end{array}$ \\
\hline Kak & 3 & 3159 & 4.89 & $\begin{array}{l}\text { The word that starts } \\
\text { as a greeting to users } \\
\text { of BRT in Semarang }\end{array}$ \\
\hline Armada & 6 & 696 & 1.08 & $\begin{array}{l}\text { Information about } \\
\text { the bus fleet to pick } \\
\text { up passengers at the } \\
\text { specified point }\end{array}$ \\
\hline
\end{tabular}

@ transsemarang provides information about the current conditions. Some of these keywords are in the form of interaction between two or more passengers using Twitter. Table III is a word or tweet that is often delivered by the Twitter account of BRT in Semarang. The number of tweets is based on the activities carried out. For example, there is a need to prevent missing information [24]. Missed information will affect the quality of services of BRT in Semarang. So far, the information conveyed explains the constraints and services of BRT in Semarang so that the public can understand and receive information well. The interaction created is equal interaction with anyone without giving special respect to certain people. It aims to avoid injustice in service [11].

Next, adaptive services try to respond to information conveyed by BRT users, via the Twitter account of @ transsemarang. It responds to questions and information mentioned in BRT in Semarang. The information submitted has characteristics such as apologies. The words such as "mohon maaf" (sorry), "kami" (we), " $k a k$ " (literally means the call for older brother or sister), and "bisa" (can) are information conveyed to respond to what is asked by BRT users.

Adaptive service responds to the wishes of the community or opinions about services provided by BRT in Semarang. It also includes information about the current conditions of service. It is in line with one of the social media functions, which is service evaluation [25].

Based on Table IV, adaptive service is a quick response that must be delivered by the Twitter account
TABLE IV

AdAPTIVE AND RESPONSIVE INFORMATION SERVICE OF Bus RAPID TRANSIT IN SEMARANG.

\begin{tabular}{|c|c|c|c|c|}
\hline Word & $\begin{array}{l}\text { Length of } \\
\text { the Word }\end{array}$ & $\begin{array}{r}\text { Count of } \\
\text { Appearance }\end{array}$ & $\%$ & Explanation \\
\hline Maaf & 4 & 449 & 0.70 & $\begin{array}{l}\text { Apology of BRT in } \\
\text { Semarang to its users }\end{array}$ \\
\hline Kak & 3 & 3159 & 4.89 & $\begin{array}{l}\text { The word that starts } \\
\text { as a greeting to users } \\
\text { of BRT in Semarang }\end{array}$ \\
\hline Kami & 4 & 1194 & 1.85 & $\begin{array}{l}\text { The answer to the } \\
\text { users of BRT in Se- } \\
\text { marang about sched- } \\
\text { ule and route informa- } \\
\text { tion. They also apol- } \\
\text { ogize for the users of } \\
\text { BRT in Semarang }\end{array}$ \\
\hline Mohon & 5 & 502 & 0.78 & $\begin{array}{l}\text { Apology of BRT in } \\
\text { Semarang to its users }\end{array}$ \\
\hline Bisa & 4 & 1099 & 1.70 & $\begin{array}{l}\text { Information to the } \\
\text { users of BRT in } \\
\text { Semarang whether } \\
\text { they can stop/ride at } \\
\text { bus stops }\end{array}$ \\
\hline
\end{tabular}

of BRT in Semarang about the services provided. The information on the condition of the bus, corridors, and routes must be given. This service shows the readiness of service providers to the needs and desires of customers. Through Twitter, the information can be delivered accurately and responded quickly. Twitter helps to be interactive in providing services and input on what should be given. Accessibility functions to answer people's rights to connect with each other and public facilities [26]. The information must be flexible [27]. As public information, it needs to be flexible and controlled so that the information can be updated within a certain time because the services provided are basic services. The information must be the main supporter to support those services.

From three mentioned indicators, each has a percentage based on word cloud analysis. The use of social media as an information tool is a form of innovation in public services. These innovations provide major changes to public transportation services [28]. The word cloud analysis shows the words that are often used by the Twitter account of BRT in Semarang in providing service information. The words often used are "kak", "koridor", and "kami". The three words appear with a large size in the word cloud analysis. These three words represent the interactive and adaptive service (kak), forms of integrated information (koridor), and responsive and transparent forms of information (kami). In this word cloud by Nvivo 12 Plus, the most frequently used words by users or admins on the Twitter account of BRT in Semarang are found (see Fig. 3). 
Cite this article as: S. H. Bokings, A. Nurmandi, and M. J. Loilatu, "How Twitter Works in Public Transportation: A Case Study of Bus Rapid Transit in Jakarta and Semarang", CommIT (Communication \& Information Technology) Journal 14(2), 53-63, 2020.

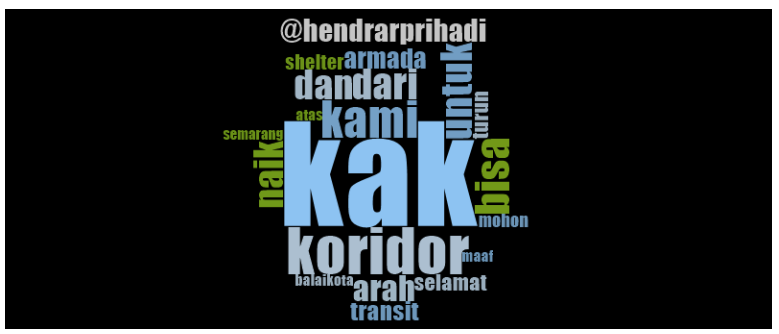

Fig. 3. Word cloud of Bus Rapid Transit in Semarang with Nvivo 12 Plus. In the picture, there are shelter, transit, Semarang, @ hendraprihadi, "kak" (literally means the call for older brother or sister), "armada" (fleet), "kami" (we), "atas" (up), "untuk" (for), "turun" (get off), "bisa" (can), "mohon" (please), "maaf" (sorry), "selamat", "arah" (direction), "balaikota" (town hall), and "naik" (ride).

\section{B. Bus Rapid Transit in Jakarta}

Information becomes the main requirement that if the community does not update the information, they will be left behind and do not know what service development should be received. Frequently, the community does not receive services transparently. There are information procedures covered so that the services provided to them do not have good value. To support public services, it is necessary to integrate services and information. It needs information to ensure service quality. The BRT in Jakarta closes the information to ensure that the provided services can be felt. It is called information management, especially in integrated services [17]. Integrated services of BRT in Jakarta connect public transportation with public facilities such as malls, offices, parks, and others. The information needs to be ensured that BRT can be connected to certain facilities.

Table $\mathrm{V}$ shows the information integration services. The words such as "pengalihan" (diversion), "rute" (route), "halte" (bus stop), "info" (information), "kawasan" (area) and "melewati" (pass) are keywords for information on services of BRT in Jakarta. These words have the same number of mentions as BRT in Semarang, as illustrated in Table IV. The most mentioned words are "rute" (4.19\%), "info" (3.48\%), and "halte" $(1.43 \%)$. These three words explain that the BRT in Jakarta passes several routes or does not pass certain routes depending on road conditions. It will also stop at certain stops. Meanwhile, "info" is the initial word when the account provides information so that the word always appears in every tweet in the Twitter account of BRT in Jakarta.

BRT in Jakarta has 13 corridors and 258 bus stops, with a total of 2276 points. With the number of corridors and bus stops, BRT in Jakarta utilizes Twitter as information media in providing services. Although it has used maps and routes as a guide, the information is
TABLE V

INFORMATION INTEGRATION OF BUS RAPID TRANSIT IN JAKARTA.

\begin{tabular}{|c|c|c|c|c|}
\hline Word & $\begin{array}{l}\text { Length of } \\
\text { the Word }\end{array}$ & $\begin{array}{r}\text { Count of } \\
\text { Appearance }\end{array}$ & $\%$ & Explanation \\
\hline Pengalihan & 10 & 129 & 1.31 & $\begin{array}{l}\text { Information about } \\
\text { route diversion of } \\
\text { BRT in Jakarta }\end{array}$ \\
\hline Rute & 4 & 412 & 4.19 & $\begin{array}{l}\text { Information about the } \\
\text { route BRT in West } \\
\text { Jakarta whether it is } \\
\text { passed by BRT or not }\end{array}$ \\
\hline Halte & 5 & 141 & 1.43 & $\begin{array}{l}\text { Information about bus } \\
\text { stops }\end{array}$ \\
\hline Info & 4 & 342 & 3.48 & $\begin{array}{l}\text { The word used in the } \\
\text { opening sentence of } \\
\text { service in BRT in } \\
\text { Jakarta }\end{array}$ \\
\hline Kawasan & 7 & 106 & 1.08 & $\begin{array}{l}\text { Information about } \\
\text { some points that are } \\
\text { not passed or closed }\end{array}$ \\
\hline Melewati & 8 & 116 & 1.18 & $\begin{array}{l}\text { Information about } \\
\text { buses of BRT in } \\
\text { Jakarta that pass or } \\
\text { do not pass certain } \\
\text { places }\end{array}$ \\
\hline
\end{tabular}

needed in real-time. Using Twitter, BRT in Jakarta can provide updated information about the services. Unlike BRT in Semarang, BRT in Jakarta is connected with other public transportation such as Mass Rapid Transit (MRT), Light Rail Transit (LRT), and Commuter Line so that the information must be in real-time. The words in Table $\mathrm{V}$ are a form of information that is continuously conveyed. It represents the services of BRT in Jakarta. As a modern transportation service, BRT in Jakarta has been developed into world-class transportation. One of the public transportation models in the world is an information system that is updated every time. Jakarta is a city with high technology level. As a smart city in Indonesia, it continues to improve. One of the characters of the smart character city is quality and integrated information [29] [29]. The type of information conveyed by BRT in Jakarta is integrated information, and this kind of model is a form of smart governance [30]. The cities in Indonesia have implemented this model to maintain service quality.

Next, interaction and transparency form open communication between two or more people about the current conditions. BRT in Jakarta uses several words as a form of interaction with its users. The content analysis in Table VI shows many words such as "jaki", "perlu tahu" (need to know), "sahabat", "tije" and "adanya" (there is/are) to indicate the form of interaction between BRT in Jakarta and its users. In contrast to BRT in Semarang, which does not use the hashtags in the information provided that the hashtags do not appear in the word frequency, the \#jaki and \#perlutahu are the information derived from the Twitter account 
Cite this article as: S. H. Bokings, A. Nurmandi, and M. J. Loilatu, "How Twitter Works in Public Transportation: A Case Study of Bus Rapid Transit in Jakarta and Semarang", CommIT (Communication \& Information Technology) Journal 14(2), 53-63, 2020.

TABLE VI

INTERACTION INFORMATION AND TRANSPARENCY OF BUS RAPID TRANSIT IN JAKARTA.

\begin{tabular}{|c|c|c|c|c|}
\hline Word & $\begin{array}{l}\text { Length of } \\
\text { the Word }\end{array}$ & $\begin{array}{r}\text { Count of } \\
\text { Appearance }\end{array}$ & $\%$ & Explanation \\
\hline \#jaki & 5 & 337 & 3.43 & $\begin{array}{l}\text { The hashtag promoted } \\
\text { by BRT in Jakarta }\end{array}$ \\
\hline \#perlutahu & 10 & 336 & 3.42 & $\begin{array}{l}\text { Information service of } \\
\text { BRT in Jakarta so } \\
\text { that users can find } \\
\text { out information about } \\
\text { Jakarta }\end{array}$ \\
\hline Sahabat & 7 & 102 & 1.04 & $\begin{array}{l}\text { A greeting to users of } \\
\text { BRT in Jakarta }\end{array}$ \\
\hline Selamat & 7 & 92 & 0.94 & $\begin{array}{l}\text { Greetings to users of } \\
\text { BRT in Jakarta such } \\
\text { as good morning or } \\
\text { good afternoon }\end{array}$ \\
\hline Tije & 4 & 108 & 1.10 & $\begin{array}{l}\text { The term for users of } \\
\text { BRT in Jakarta }\end{array}$ \\
\hline Adanya & 6 & 189 & 1.92 & $\begin{array}{l}\text { Information about ac- } \\
\text { tivities on the route of } \\
\text { BRT in Jakarta }\end{array}$ \\
\hline
\end{tabular}

of BRT in Jakarta. BRT builds branding about public transportation to the public. In Table VI, the words "sahabat", "selamat", and "tije" are the initial words used to greet users of BRT in Jakarta. The type of interaction information and transparency in the Twitter account also uses self-branding to promote BRT.

Table VI explains several points, such as transparency in the example of the service (adanya). The word shows that the BRT in Jakarta is experiencing or not experiencing disturbances. For example, there is a change of route, a road improvement, an engine failure, or a change in schedule. Hence, this word is a sign that the services provided by BRT in Jakarta are transparent to its users. Compared to BRT in Semarang, this word does not appear. It is influenced by the intensity of users and the number of vehicles operating in BRT in Semarang. Public organizations in providing services use language or words as self-branding. The branding is easily understood by searching for the information [24]. BRT in Jakarta as public transportation uses this method.

Then, adaptive and responsive service shows the readiness of the government to serve the community. If it cannot respond and adapt to the community's wants and needs, the service is considered a failure. BRT in Semarang and Jakarta is public transportation that supports the work of Semarang and Jakarta people. Based on the content analysis approach of BRT in Jakarta, the words that represent adaptive and responsive services including "selamat", "mengalami" (experience), "beroperasi” (operate), "kawasan" (area), and "melewati" (pass). The words in Table VII have their respective explanations. The word processing shows that the often-used words are "mengalami" with
TABLE VII

ADAPTIVE AND RESPONSIVE INFORMATION SERVICE OF BUS RAPID TRANSIT IN JAKARTA.

\begin{tabular}{|c|c|c|c|c|}
\hline Word & $\begin{array}{l}\text { Length of } \\
\text { the Word }\end{array}$ & $\begin{array}{r}\text { Count of } \\
\text { Appearance }\end{array}$ & $\%$ & Explanation \\
\hline Selamat & 7 & 92 & 0.94 & $\begin{array}{l}\text { Greetings to users of } \\
\text { BRT in Jakarta such } \\
\text { as good morning or } \\
\text { good afternoon }\end{array}$ \\
\hline Mengalami & 9 & 157 & 1.60 & $\begin{array}{lr}\text { Information } & \text { about } \\
\text { BRT in Jakarta } \\
\text { when it experiences } \\
\text { diversion } \\
\text { disruption }\end{array}$ \\
\hline Beroperasi & 10 & 93 & 0.95 & $\begin{array}{l}\text { The word used to de- } \\
\text { scribe a bus, bus stop, } \\
\text { or corridor that is op- } \\
\text { erating or not operat- } \\
\text { ing }\end{array}$ \\
\hline Kawasan & 7 & 106 & 1.08 & $\begin{array}{l}\text { Information about } \\
\text { some points that are } \\
\text { not passed or closed }\end{array}$ \\
\hline Melewati & 8 & 116 & 1.18 & $\begin{array}{l}\text { Information about } \\
\text { buses of BRT in } \\
\text { Jakarta that pass or } \\
\text { do not pass certain } \\
\text { places }\end{array}$ \\
\hline
\end{tabular}

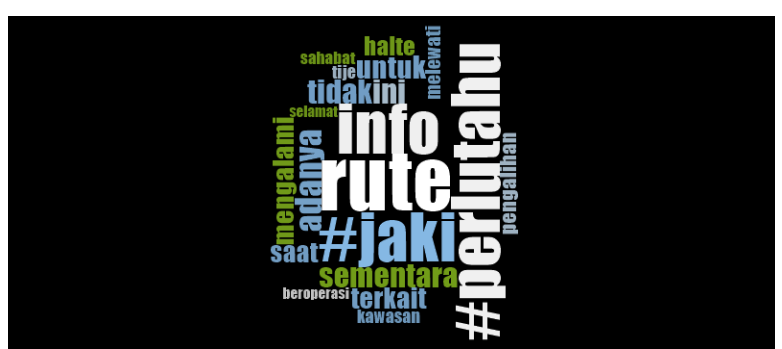

Fig. 4. Word cloud of Bus Rapid Transit in Jakarta with Nvivo 12 Plus. In the picture, there are "sahabat", "tije", "selamat", \#jaki, \#perlutahu (need to know), "halte" (bus stop), "untuk" (for), "melewati" (pass), "mengalami" (experience), "adanya" (there is/are), "info" (information), "rute" (route), "saat" (when), "sementara" (currently), "beroperasi" (operate), "terkait" (about), "kawasan" (area), and "pengalihan" (diversion).

$1.60 \%$ or 157 times, "melewati" with $1.18 \%$ or 116 times, and "kawasan" with $1.08 \%$ or 106 times.

The words in Table VII explain whether the bus experiences diversion or disruption, passes through certain stops, and operates in certain stops. Its users will quickly get information about the services. The five words can be interpreted as a form of information that is adaptive and responsive. The public transportation function designed to save time and money can function well with the information provided by the Twitter account of BRT in Jakarta. The access to information is easy and can be controlled. It makes the services of BRT in Jakarta well-controlled [27]. The type of available communication also opens to evaluations given by Jakarta BRT users through social media [25]. So far, the Twitter account of BRT in Jakarta has 
Cite this article as: S. H. Bokings, A. Nurmandi, and M. J. Loilatu, "How Twitter Works in Public Transportation: A Case Study of Bus Rapid Transit in Jakarta and Semarang", CommIT (Communication \& Information Technology) Journal 14(2), 53-63, 2020.

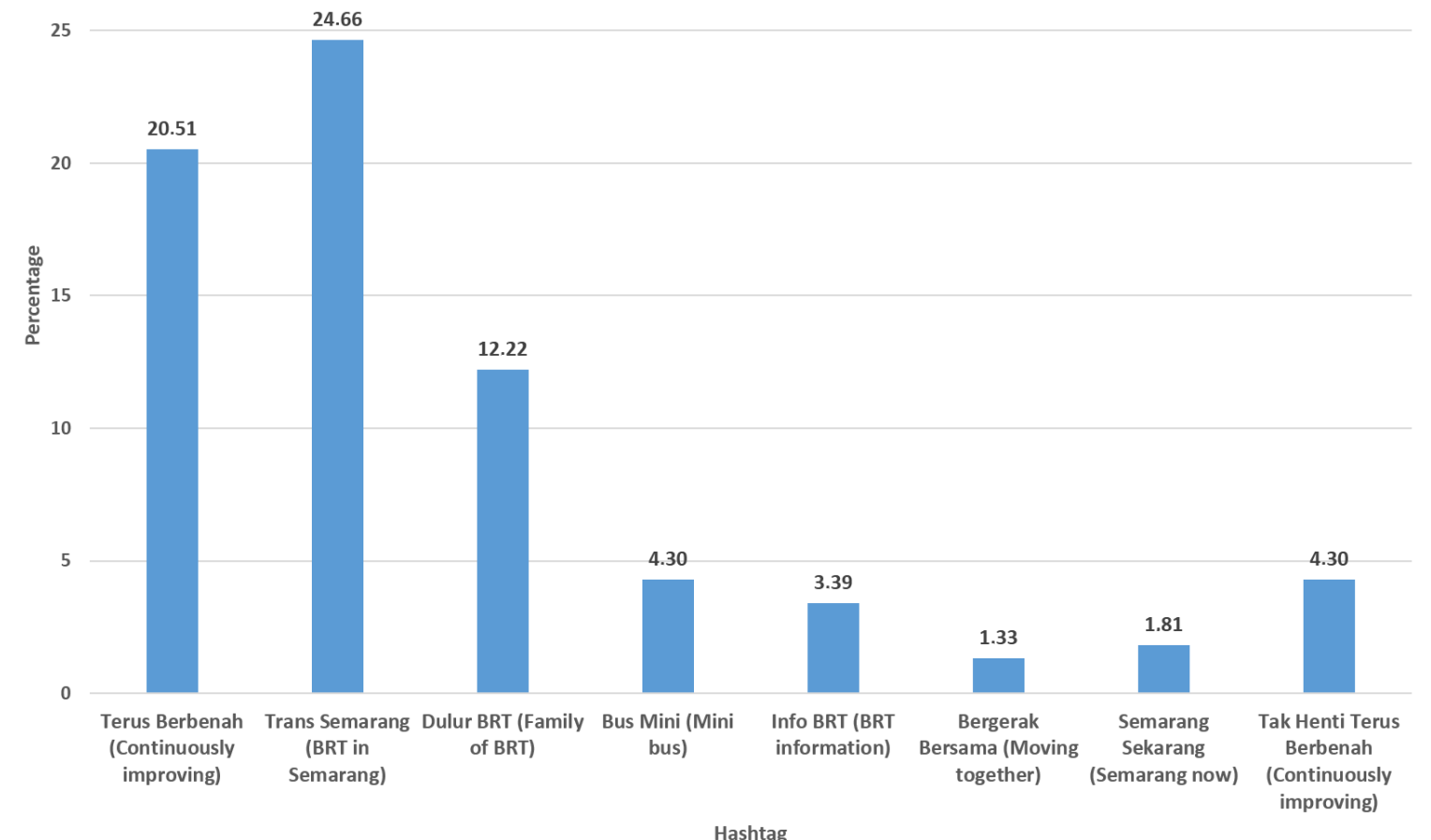

Fig. 5. The hashtags in the Twitter account of Bus Rapid Transit in Semarang.

responded to its users about services, whether they have problems or vice versa. In this word cloud by Nvivo 12 Plus, the most frequently used words by users or admins on the Twitter account of BRT in Jakarta are found (see Fig. 4).

\section{Use of Hashtags as Public Transportation Cam- paigns}

A hashtag is information that wants to be popularized in Twitter social media. The purpose is to be easily identified and become one of the information that is often conveyed. In addition to being a keyword, hashtag functions as a form of the campaign on Twitter. Twitter accounts of BRT in Semarang and Jakarta have different information characteristics. Although both of them are public transportation accounts, the services have information criteria. Through the hashtag, it can be dictated by the characteristics and form of information. The hashtag is also used as a campaign to the community about changes such as the environment, services, and congestion when using friendly, emissions-free, and modern public transportation.

Figure 5 shows the hashtag of BRT in Semarang. The highest number of hashtags is \#transsemarang
(24.66\%), \#terusberbenah (20.51\%), and \#dulurbrt $(12.22 \%)$. These three hashtags are often used by the Twitter account of BRT in Semarang but with quite a small amount. The percentage of usage of hashtags that do not reach $30-50 \%$ shows that the intensity of the communication made by this account is not so intense. Meanwhile, the hashtags with the least amount are \#bergerakbersama (1.33\%) and \#semarangsekarang $(1.81 \%)$. The hashtag is based on certain events such as the anniversary of Semarang, Indonesian Independence Day, and others. Based on the most used hashtag, each has its function. There is the hashtag having messages and invitations to the public to use the BRT in Semarang. The hashtag (\#terusberbenah) in using the BRT in Semarang asks the community to participate in developing Semarang. The hashtag (\#transsemarang) is an example of information about the activities and services carried out by BRT in Semarang. Then, hashtag (\#dulurbrt) is the identity and use of local languages as a sign of communication. It is different from the BRT in Jakarta, which uses the Indonesian language because of the people's heterogeneity and characteristics from several regions in Indonesia. Thus, the use of the language illustrates the culture of the region. 
Cite this article as: S. H. Bokings, A. Nurmandi, and M. J. Loilatu, "How Twitter Works in Public Transportation: A Case Study of Bus Rapid Transit in Jakarta and Semarang", CommIT (Communication \& Information Technology) Journal 14(2), 53-63, 2020.

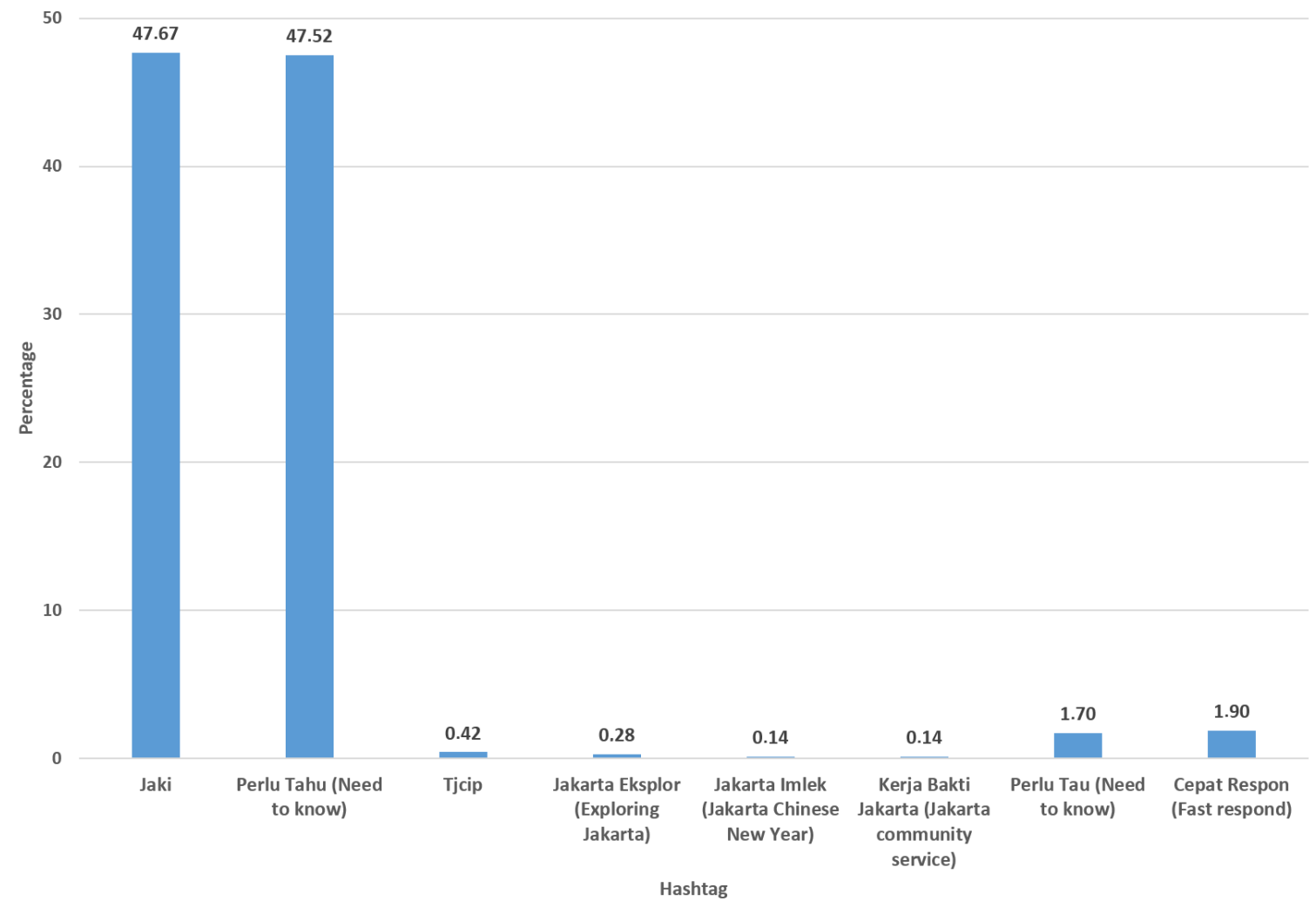

Fig. 6. The hashtags in the Twitter account of Bus Rapid Transit in Jakarta.

The hashtags of BRT in Jakarta are more consistent (see Fig. 6). It uses two main hashtags, namely \#jaki and \#perlutahu. The @PT_Transjakarta account often uses these hashtags in providing information. Meanwhile, the other hashtags such as \#perlutahu and \#cepatrespon appear in certain conditions such as floods, fire, and other disasters that require the government to respond more quickly. The number of hashtag usages of BRT in Jakarta has been higher compared to BRT in Semarang. The hashtag (\#jaki) is a Jakarta Transportation campaign. It aims at the community to use BRT in Jakarta as the main transportation. In addition to the hashtag, it is also in line with the mode of public transportation provided by a mutually connected government. The other hashtag (\#perlutahu) shows information conveyed by the management of BRT in Jakarta. The hashtag provides information about other services.

Based on the function, the two accounts are promotion media of public transportation that is convenient and safe for the community. The carried out promotions are marked by their respective hashtags. The number of hashtags is affected by the number of tweets between the two accounts, bus mobility, and the community. The information conveyed depends on the service of BRT, but it is not uncommon for information to be hidden outside of its activities such as tourism or city promotion. As a socialization tool, the two accounts have relationships or networks with other accounts to share information. Figures 5 and 6 are the analysis of Nvivo 12 Plus using a timeline by hashtag. The hashtag timeline shows the number of hashtags often used by Twitter accounts of BRT in Semarang and Jakarta. From the number, BRT in Semarang has more hashtag compared to BRT in Jakarta. However, BRT in Jakarta has higher intensity.

Nvivo 12 Plus displays the hashtag feature. The analysis helps display posts with hashtags that are often used by BRT in Semarang and Jakarta. From the analysis results, the hashtag is to market or popularize public transportation in Semarang and Jakarta. The hashtag functions to differentiate the information on Twitter. Both Twitter accounts have succeeded in popularizing and influencing the community to shift private transportation to public transportation. BRT in Semarang and Jakarta has implemented knowledge management in managing BRT information [31]. Knowledge management is an applicative development 
Cite this article as: S. H. Bokings, A. Nurmandi, and M. J. Loilatu, "How Twitter Works in Public Transportation: A Case Study of Bus Rapid Transit in Jakarta and Semarang", CommIT (Communication \& Information Technology) Journal 14(2), 53-63, 2020.

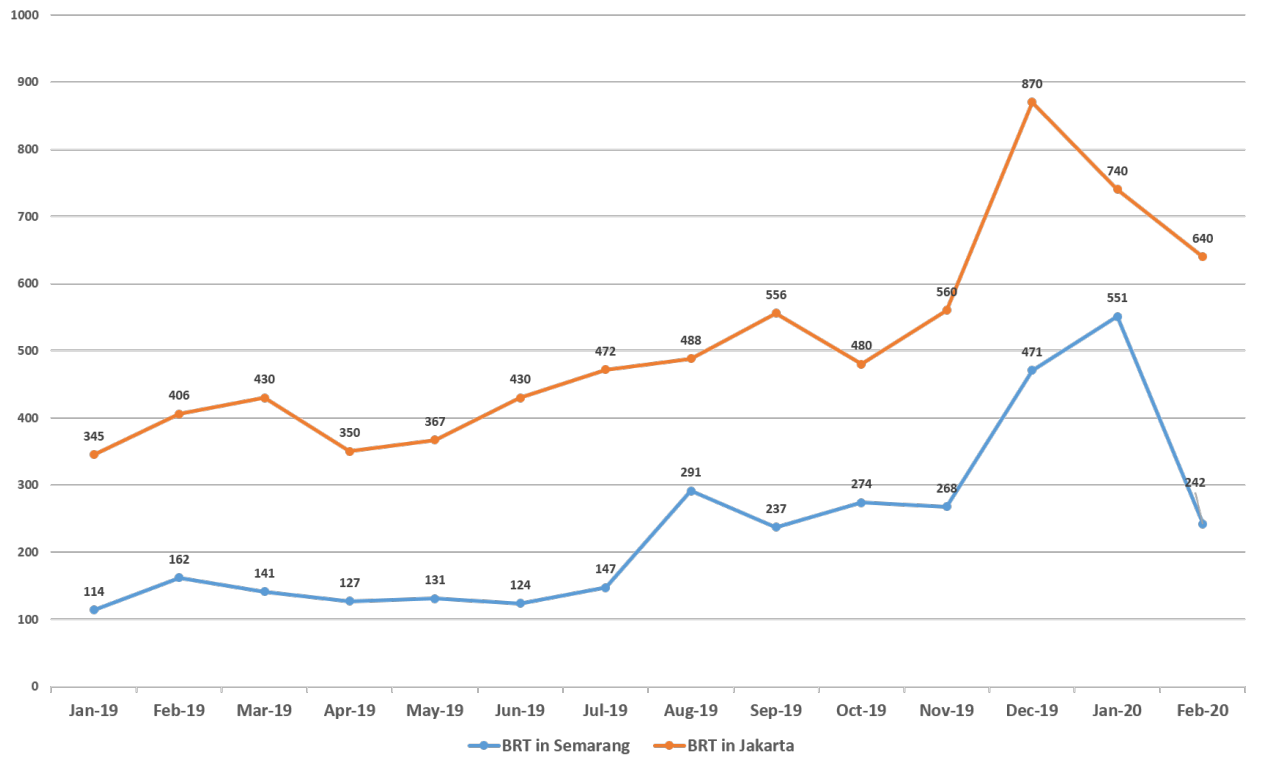

Fig. 7. Information Intensity of Bus Rapid Transit in Semarang and Jakarta.

of information management in public transportation so that information management responds to the needs of the community [14].

\section{Tweet Intensity of BRT in Semarang and Jakarta}

Information about the services of BRT in Semarang and Jakarta is delivered at different times. It is influenced by the number of BRT users and the number of Twitter users so that the interaction will depend on both. Based on the results of chat analysis on Nvivo 12 Plus, it shows that the information intensity conveyed by the Twitter account of BRT in Jakarta is higher than BRT in Semarang. Several factors influence the amount of information conveyed. First, it is the number of corridors of BRT in Semarang and Jakarta. Second, the number of fleets of BRT in Semarang and Jakarta. Third, it is the mobility of the community in using BRT. Last, there is convenience in using BRT.

Figure 7 explains that the information intensity delivered by the Twitter account of BRT in Jakarta is higher each month than BRT in Semarang. The number of tweets can be affected by activities such as socialization and other holidays. As in December 2019 to January 2020, the information intensity increases significantly. The increase has occurred in early 2020, so it means more information is conveyed. This amount of information is caused by the increased number of BRT users.

\section{CONCLUSION}

There are three conclusions achieved from the research. First, the functions of the two accounts run well in providing information service, but the intensity of the information delivered varies. The account of BRT in Jakarta has a high level of information delivery. From the Ncapture data results using Nvivo 12 Plus, the information from the account of BRT in Jakarta is relatively high each month. Jakarta's big agenda and activities influence the increase in the number of tweets so that information initiates to become higher. Meanwhile, the amount of information conveyed by the account of BRT in Semarang is lower. Second, the account of BRT in Jakarta is responsive. It responds to the questions or mentions given by its users. Meanwhile, other forms such as route, change, transparency, adaptiveness, and responsiveness are well. The function can be seen based on the information delivered. Both services can be measured based on the number of users and the amount of information provided. Third, the account of BRT in Semarang has a different identity from the BRT in Jakarta. The identity can be seen based on the use of local languages in the delivery of information. For this reason, the research can provide guidance or inspiration to all parties involved to develop the research further. Based on the result, the researchers propose future research using other social media such as Instagram and Facebook as popular social media in Indonesia.

\section{REFERENCES}

[1] H. Pienrasmi, "Pemanfaatan social media oleh praktisi public relations di Yogyakarta," Jurnal Komunikasi, vol. 9, no. 2, pp. 199-210, 2015. 
Cite this article as: S. H. Bokings, A. Nurmandi, and M. J. Loilatu, "How Twitter Works in Public Transportation: A Case Study of Bus Rapid Transit in Jakarta and Semarang”, CommIT (Communication \& Information Technology) Journal 14(2), 53-63, 2020.

[2] H. Widowati. (2019) Berapa jumlah kendaraan di DKI Jakarta? Jumlah kendaraan di Jakarta berdasarkan jenis (2012-2018). [Online]. Available: https://databoks.katadata.co.id/datapublish/2019/ 08/02/berapa-jumlah-kendaraan-di-dki-jakarta

[3] M. K. Imran, S. M. J. Iqbal, U. Aslam, and T. Fatima, "Does social media promote knowledge exchange? A qualitative insight," Management Decision, vol. 57, no. 3, pp. 688-702, 2019.

[4] B. P. L. Lau, S. H. Marakkalage, Y. Zhou, N. U. Hassan, C. Yuen, M. Zhang, and U. X. Tan, "A survey of data fusion in smart city applications," Information Fusion, vol. 52, pp. 357-374, 2019.

[5] S. Molinillo, R. Anaya-Sánchez, A. M. Morrison, and J. A. Coca-Stefaniak, "Smart city communication via social media: Analysing residents' and visitors' engagement," Cities, vol. 94, pp. 247$255,2019$.

[6] W. J. Elving and R. M. Postma, "Social media: The dialogue myth? How organizations use social media for stakeholder dialogue," in How Strategic Communication Shapes Value and Innovation in Society. Emerald Publishing Limited, 2017, pp. 123-141.

[7] S. Pezanowski, A. M. MacEachren, A. Savelyev, and A. C. Robinson, "SensePlace3: A geovisual framework to analyze place-time-attribute information in social media," Cartography and Geographic Information Science, vol. 45, no. 5, pp. 420-437, 2018.

[8] M. Hämäläinen, "A framework for a smart city design: Digital transformation in the Helsinki smart city," in Entrepreneurship and the Community. Springer, 2020, pp. 63-86.

[9] A. Camero and E. Alba, "Smart city and information technology: A review," Cities, vol. 93, pp. 84-94, 2019.

[10] T. Wang, A. Hussain, M. N. M. Bhutta, and Y. Cao, "Enabling bidirectional traffic mobility for its simulation in smart city environments," Future Generation Computer Systems, vol. 92, pp. 342-356, 2019.

[11] A. Kacem, R. Belkaroui, D. Jemal, H. Ghorbel, R. Faiz, and I. H. Abid, "Towards improving e-government services using social media-based citizen's profile investigation," in Proceedings of the $9^{\text {th }}$ International Conference on Theory and Practice of Electronic Governance, Montevideo Uruguay, March 2016, pp. 187-190.

[12] N. Rebernik, B. G. Marušić, and A. Bahillo, Understanding the complexity of inclusive public space design-Reflections on the case study of
Slovenia, ser. Neighbourhood \& City-Between Digital and Analogue Perspectives. Lisbon: Edies Universitrias Lusfona, 2019, pp. 309-318.

[13] P. Jaiswal and S. Hatkar, "Inclusive planning: Smart solution for city design," International Journal on Emerging Technologies, vol. 8, no. 1, pp. 521-523, 2017.

[14] E. Holden, K. Linnerud, and D. Banister, "Sustainable passenger transport: Back to Brundtland," Transportation Research Part A: Policy and Practice, vol. 54, pp. 67-77, 2013.

[15] M. Itoh, D. Yokoyama, M. Toyoda, Y. Tomita, S. Kawamura, and M. Kitsuregawa, "Visual exploration of changes in passenger flows and tweets on mega-city metro network," IEEE Transactions on Big Data, vol. 2, no. 1, pp. 85-99, 2016.

[16] V. Kurganov, M. Gryaznov, and A. Dorofeev, "Management of transportation process reliability based on an ontological model of an information system," Transportation Research Procedia, vol. 36, pp. 392-397, 2018.

[17] M. Stone, J. Knapper, G. Evans, and E. Aravopoulou, "Information management in the smart city," The Bottom Line, vol. 31, no. 3/4, pp. 234-249, 2018.

[18] H. K. Mohajan, "Qualitative research methodology in social sciences and related subjects," Journal of Economic Development, Environment and People, vol. 7, no. 1, pp. 23-48, 2018.

[19] A. B. Hamilton and E. P. Finley, "Qualitative methods in implementation research: An introduction," Psychiatry Research, vol. 280, no. October, p. 112516, 2019.

[20] C. Brandão, "P. Bazeley and K. Jackson, qualitative data analysis with Nvivo ( $2^{\text {nd }}$ ed.)(2013). London: Sage," Qualitative Research in Psychology, vol. 12, no. 4, pp. 492-494, 2015.

[21] N. H. Woolf and C. Silver, Qualitative analysis using Nvivo: The five-level QDA method. Routledge, 2017.

[22] O. A. Shvetsova, "Smart education in high school: New perspectives in global world," in 2017 International Conference Quality Management, Transport and Information Security, Information Technologies (IT\&QM\&IS). St. Petersburg, Russia: IEEE, Sept. 24-30, 2017, pp. 688691.

[23] B. Flügge, Smart Mobility-Connecting Everyone: Trends, Concepts and Best Practices. Springer, 2017.

[24] A. L. Kavanaugh, E. A. Fox, S. D. Sheetz, S. Yang, L. T. Li, D. J. Shoemaker, A. Natsev, 
Cite this article as: S. H. Bokings, A. Nurmandi, and M. J. Loilatu, "How Twitter Works in Public Transportation: A Case Study of Bus Rapid Transit in Jakarta and Semarang", CommIT (Communication \& Information Technology) Journal 14(2), 53-63, 2020.

and L. Xie, "Social media use by government: From the routine to the critical," Government Information Quarterly, vol. 29, no. 4, pp. 480491, 2012.

[25] V. Grubmüller, K. Götsch, and B. Krieger, "Social media analytics for future oriented policy making," European Journal of Futures Research, vol. 1, no. 1, p. 20, 2013.

[26] J. S. De Oliveira Neto, "Inclusive smart cities: Theory and tools to improve the experience of people with disabilities in urban spaces," Ph.D. dissertation, Universidade de São Paulo \& Université Paris-Saclay, 2018.

[27] R. Pérez-Delhoyo, C. García-Mayor, H. Mora, V. Gilart-Iglesias, and M. D. Andújar-Montoya, "Improving urban accessibility: A methodology for urban dynamics analysis in smart, sustainable and inclusive cities," International Journal of Sustainable Development and Planning, vol. 12, no. 3, pp. 357-367, 2017.

[28] B. Verma, R. Snodgrass, B. Henry, B. Smith, and T. Daim, "Smart cities-an analysis of smart transportation management," in Managing innovation in a global and digital world. Springer, 2020, pp. 367-388.

[29] D. G. Costa, C. Duran-Faundez, D. C. Andrade, J. B. Rocha-Junior, and J. P. Just Peixoto, "Twittersensing: An event-based approach for wireless sensor networks optimization exploiting social media in smart city applications," Sensors, vol. 18, no. 4, p. 1080, 2018.

[30] G. Kousiouris, A. Akbar, J. Sancho, P. Ta-Shma, A. Psychas, D. Kyriazis, and T. Varvarigou, "An integrated information lifecycle management framework for exploiting social network data to identify dynamic large crowd concentration events in smart cities applications," Future Generation Computer Systems, vol. 78, pp. 516-530, 2018.

[31] T. M. Nisar, G. Prabhakar, and L. Strakova, "Social media information benefits, knowledge management and smart organizations," Journal of Business Research, vol. 94, no. January, pp. 264272, 2019. 